\title{
Use of Mobile Phones to Support Coursework: Evidence from Wa Polytechnic, Ghana
}

\author{
Zakaria Ismail Mahamud \\ Department of Information and Communication Technology \\ Wa Polytechnic, Wa, Ghana \\ Email: $\underline{\text { imouktar@yahoo.com }}$ \\ Fordjour K. Andrews \\ Department of Information and Communication Technology \\ Wa Polytechnic, Wa, Ghana. \\ Email: fordjourandrews@yahoo.com \\ and \\ Afriyie K. Rockson \\ Department of Information and Communication Technology \\ Wa Polytechnic, Ghana. \\ Email: e.afriyie@yahoo.com \\ DOI//http://dx.doi.org/10.4314/gjdsv12i1\&2.12
}

\begin{abstract}
The recent use of the mobile phone as a learning tool in tertiary institutions in Ghana has generated a lot of academic interest. What has even become more interesting is how the mobile phone and its usage can be adopted to respond to different educational environments as well as teaching and learning experiences. But there seems to be little research on how students of Wa Polytechnic fully explore the mobile phone technology in their coursework. This paper investigates how students of Wa Polytechnic use the mobile phone as an interactive medium to access educational content to support coursework and the challenges that confront them. The survey approach was employed for the research and a simple random sampling technique was used to select 300 respondents from a population of 1,269 students. The study revealed that $82 \%$ of the students use mobile phone to support coursework. The major challenge that faces students as they use mobile phones to support coursework is poor network service. Other relatively moderate challenges include inadequate knowledge in the use of mobile phones, faulty mobile phones, and lack of Microsoft Office applications in their mobile phones. The study recommends
\end{abstract}


the introduction of Mobile Service System Design and Assembling and Repair of Mobile Phones as courses incorporating the use of mobile phones. Mobile service providers should innovatively improve network stability during school sessions for students to effectively use mobile phone to support course work.

Keywords: Mobile Phone, Coursework, Interactive Medium, Mobile Service Provider, Mobile Phone Subscriptions

\section{INTRODUCTION}

Since Martin Cooper made the first mobile telephone call in 1973, the use of the technology has assumed various dimensions. Great innovation in mobile phone development over the years has made the cell phone evolved into more than just a device used for making voice calls. In addition to telephony, smartphones, mobile phones with more advanced computing ability through the use of native software applications, have features such as Global Positioning System (GPS) navigation; music playback, bluetooth, video camera and internet access. These features enable them support a wide variety of services such as text messaging, multimedia messaging service (MMS), WhatsApp, viber, email, business applications, gaming, photography, and video. Mobile phone subscribers such as teachers, students, make real use of this facility to access the internet for teaching and learning.

The telegraph installation in 1881 marked the beginning of Ghana telecommunication drive (Allotey \& Akorli, 1999) and the subsequent development in this direction witnessed a tele-density of 0.3 main lines in 1950. There seemed to be no significant progress in this sector for forty years thereafter (Michelsen, 2003). Eighty percent of available lines (of which 53.6\% located in Accra) were only in the urban areas (Overa, 2006). The communication saw a massive improvement when Ghana Post and Telecommunication was diversified into Ghana Telecom in 1995 and the emergence of the internet and mobile services made the situation better (Frempong, George and Emmanuel, 2007). The first cellular phone service in Ghana was initiated by Mobitel (now tiGo) in 1992 with only 19,000 Ghanaians owning mobile phones (Telephones and Communication, 2013). The number of mobile phone subscribers increased to 43,00o and 68,000 in 1998 and 1999 respectively. The number of mobile phone service providers also increased from 1 to 5 and the usage also increased from 68,000 in 1999 to 218 ,000 subscribers in 2000. As at the end of 2005, mobile phone users in the country reached 3,000,000, with overwhelmingly popular use in the cities (Ghanaweb, 2005). According to National Communication Authority (NCA), the total mobile subscription volume was about 14, 242, 476 in 2009 with a monthly growth rate of $2.5 \%$ (NCA, 2009). The total cellular voice subscriber base in Ghana as at November, 2012 stood at 25,344,745 (Ghanaweb, 2013).

Global statistics estimated that at the end of 2012, there were 6.8 billion mobile phone subscriptions (International Telecommunication Union, 2013). This is quantified to be equivalent to $96 \%$ of the world population of 7.1 billion according to International 
Telecommunication Union (ITU); an increase from 5.4 billion to 6.0 billion subscribers in 2010 and 2011 respectively. It is also reported that mobile subscription in the developed world is fast reaching a point with at least one mobile subscription per person with penetration quoted to be around $128 \%$ of the population. However, mobile phone penetration in the developing world is said to be $89 \%$ of the population, with Africa being the lowest region worldwide. It is predicted that the mobile subscribers worldwide will reach 7.0 billion by the end of 2013; 7.5 billion by the end of 2014 and 8.5 billion by the end of 2016. Africa and Middle East will overtake Europe as the second largest region for mobile subscribers after Asia Pacific (Portio Research, 2013). Ericsson forecasts that mobile phone subscription will reach 6.6 billion at the end of 2012 and 9.3 billion in 2018 (Global Mobile Statistics, 2013).

\section{Types of mobile Phones}

A smartphone is a mobile phone with more advanced computing capability and connectivity than a feature phone which has a limited functionality. The first smartphones combined the functions of a personal digital assistant (PDA) with a mobile phone. Later models added the functionality of portable media players, low-end compact digital cameras, pocket video cameras, and GPS navigation units to form one multi-use device. Many modern smartphones also include high-resolution touch screens and web browsers that display standard web pages as well as mobile-optimised sites. Another defining aspect of a smartphone is its ability to multitask between applications and operations. Fairphones are types of smartphones which are designed and developed with ecological and ethical issues foremost in mind. They are made from recycled, recyclable and responsibly-sourced goods with minimal packaging such that if one component breaks down or the user wants to update it, only that particular component is replaced.

Feature phones are low-end mobile phones that do not have the computing power of smartphones. They are generally limited in capabilities and typically provide voice calling and text messaging functionality with basic multimedia and internet capabilities. Feature phones predominantly run on a proprietary Java Micro Edition platform and can only run basic applications. It should be noted that the capability gap between smartphones and feature phones is rapidly becoming narrower everyday as feature phones are becoming more advanced. Thus, the smartphone phone of today may become a feature phone years to come.

\section{Uses of Mobile Phones in Educational Context}

Mobile phones have a wide range of educational attributes, such as spontaneity, informality, portability, personalisation, ubiquity, pervasiveness and the functions such as voice, text, video, radio, and the internet (Kukulska-Hulme, Evans \& Traxler, 2005). These days, school administrators, educators and teachers of higher institutions of learning have come to terms with the reality that students use a variety of mobile 
technology for various academic purposes. Students in Nigeria use the mobile phone to communicate with their lecturers in delivering a coursework, gather data and get access to Online Public Access Catalogue for information sharing (Utulu, 2012). Schedules for tutorials or meeting research supervisors are known by students in advance through the use of mobile phone in Makerere University (Kajumbula, 2006). In South Africa, some m-learning programmes have become successful due to easy access to mobile phone especially in terms of teaching Biology (UNESCO, 2012). Most mobile phones have flashlights that are used, more especially in the absence of electricity to study. The availability and use of the mobile phone technology in Africa, Middle East and Asia will enhance coursework in the form of learner-teacher or learner-learner collaborative learning (UNESCO, 2012). An application called Short Messaging Service (SMS) is employed to assist students to learn foreign language and teachers use SMS to communicate with their students as observed by Cui and Wang (2008). SMS is used to pop quizzes to students, information sharing on timetable and reminder of examination dates in higher schools in the UK (Ferry, 2009). Browsers applications such as Opera Mini, Mozilla, Firefox, Internet Explorer, and Google Chrome enable students to watch a lecture conveniently using either the mobile phone or television (TV) in the classroom (Kafyulilo, 2012). And by this, students can manage their learning schedule synchronously or asynchronously for a better benefit. Mobile phones with digital camera facility are used to take educational photos when on field trip; exchange the photos by sending them as e-mail attachments.

According to Commonwealth of Learning (2008), digital camera as a feature of the mobile phone makes it possible for the learner to document instructional visual resources and scientific facts which can be retrieved when needed. It therefore appears that students with appropriate mobile phones can have their interest aroused at any time to interactively engage in learning anywhere anytime. Internet-enabled mobile phones have enormous software resources put at the disposal of the learner to support all kinds of academic activities through mobile learning (m-learning) as buttressed by Guy (2009). According to Ferry (2009), a mobile phone can be used as a technological tool to access internet content, remix it to create other goods and services for the classroom teacher and other global consumers. Mobile phones can increase access in those situations where cost represents a significant barrier to learning (Bradley, Weiss \& Davies, 2010). Developing interactive mobile-learning programmes at all levels of education can help address or reduce to the barest minimum some of the learning problems caused by distance (Huang, Y-M., Hwang W - Y. \& K - E, 2010). Bradley and Cook (2010) arguably claim that mobile phone technology can motivate students to learn actively in a teaching-learning setting and suitable activities can be designed to arouse the interest of other students to partake in the learning for a sustainable duration of time. According to (Huang et al., 2010), mobile learning applications can engage students not only to learn content conveniently but also give them access to remote educational content. The learning process even becomes improved when the mobile platform is empowered by internet browser to allow learners exchange e-mails, attachments, chats, web-based conference inter alia (Tinio, 2003). This provides a conducive atmosphere for access and collaboration in learning that offers 
variety of assessment methods for reinforcement (Wijekumar, 2005). As claimed by Cui and Wang (2008), some institutions of higher learning in United Kingdom (UK) have been able to harness the use of mobile phone for the storage and retrieval of e-books, lecture notes and examination results so as to facilitate the learning process. It is also observed that the mobile phone can provide information on timelines for submission of assignments, timetable and changes in lecture rooms in some tertiary institutions (Liaw, 2009). Students in China use the mobile phone to access English learning material as well as online evaluation tests Cui and Wang (2008).

\section{Policy on Mobile Phone Usage in Some Tertiary Institutions}

In Wa Polytechnic, students are allowed to possess and use mobile phones. But as there is the tendency for the students to use them to cheat during examinations, Wa Polytechnic has a policy on the possession and use of mobile phones during examinations. "The phone use policy developed by the Wa Polytechnic Academic Board makes the possession and use of phones during examinations an offense" (Dansieh, 2011: 14). For this reason, students are not allowed to bring mobile phones to the examination hall. If a student is found with a mobile phone in the course of writing examinations, the phone is confiscated and the offender's paper is cancelled and made to pay an amount of twenty Ghana cedis after which the mobile phone is returned to him or her. If a student is found cheating or deemed to have cheated with the mobile phone, which constitutes examination malpractices, the penalty for this offense is withdrawal from the Polytechnic (Students' Handbook, 2009).

Investigation on policy of institutions on mobile phones possession and usage revealed that most of the institutions do not have a clear cut institution-wide policy regarding mobile phones in the classroom. Instead, it is left to the discretion of the individual instructor or lecturer. The institutions were, however, unanimous in rules and regulations governing the possession and usage of the mobile phones during examinations. They do not allow mobile phones to be taken into the examination room. According to the Students' Handbook of University of Education inWinneba, Ghana,no mobile phone, radio, or any communication equipment is to be taken into the examination room; failure to comply with this rule may lead to confiscation of the gadget. The University for Development Studies general and examination rules and regulations on first degree and diploma programmes stipulate that candidates shall not take into examination room or have in possession during an examination a mobile phone (Students' Handbook, 2014). The corresponding penalty for violating this rule is the cancellation of candidate's paper (s) and confiscation of the gadget. TheUniversity of Pretoria does not allow cell phones to be taken to test or examination venues (Academic Administration, 2010). A survey indicates that professors have cell phone policies that do not allow students to use the mobile devices during classes (HOPKE, 2009). However, HOPKE (2009) indicates that it is difficult to enforce a policy that would ban cell phones in college classrooms. At Villanova University School of Law in USA, possession and use of mobile phones during classes, lectures, meetings, and other presentations is not permitted. The policy requires all mobile phones to be turned off in such occasions. The use of mobile phones in an 
examination is a violation of the school's code of conduct. However, if emergency requires a cell phone to be on, it must be a silent signal, and the individual must leave the room to take the emergency call (Students' Handbook, 2014).

\section{Challenges of Using Mobile Phone to Support Coursework}

Despite its huge potential for learning, there are a number of challenges which have the tendency to derail the use of the mobile phone in education (Kirschner \& Selinger, 2003). The wide diversity among mobile devices in terms of available features and proprietary platforms and designs are not always optimal for learners owing to limited capabilities for text entry, small screen sizes, and limited battery life (Shuler, 2oogas cited in Deubel, 2009). The mobile devices are too small and impractical for entering large amounts of text at one time as one might do quickly using a standard keyboard.Furthermore, the use of the mobile phone to interactively teach and learn at the primary and secondary school levels in Ghana is not being encouraged at all because students are banned from possessing and using their phones during school hours. When 'internet' generation students become far ahead of their teachers in ICT knowledge, and the gap is not closed in time, schooling becomes dull, resulting in frustration and ultimately students become drop-outs (Kennedy \& Krause, 2007). Wulystan, Roland, Andrew \& Rachel (2012) assert that the incompatibility of mobile phone applications with academic software like Microsoft Excel, Portable File Format (Pdf) files and PowerPoint application as well as the small size nature of the mobile phone screen are potential threats to m-learning success.

\section{RESEARCH METHODOLOGY}

A survey methodology was used to obtain data from the respondents. A simple random sampling procedure was used to select a sample of 300 respondents from a population of 1,269 students. The simple random sampling method was used to avoid selection biases. The data collection instrument used was a questionnaire. Out of the 300 questionnaires given to respondents, 244 were completed and returned. The sampling units were: Higher National Diploma students, Diploma in Business Studies and Certificate students.

\section{Data Analysis and Discussion}

It was found that whereas majority of the respondents, $83.9 \%$ use mobile phone to facilitate their academic work, minority, $16.1 \%$ of the respondents say they do not use their mobile phones to support coursework. This revelation establishes a fact that the usage of mobile phones to support coursework in Wa Polytechnic is high. 


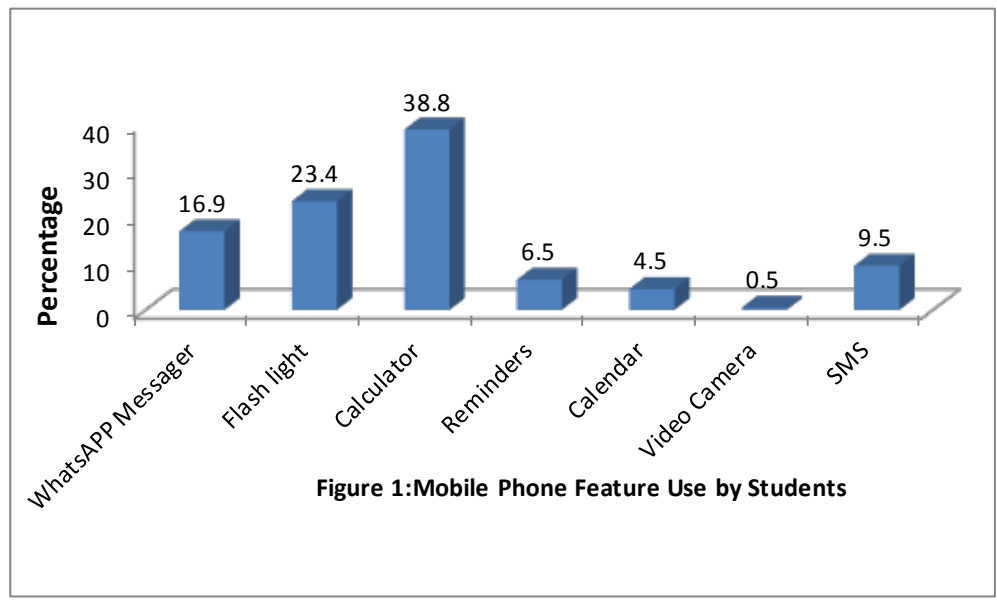

Figure 1: Mobile phone features use by students

Figure 1 indicates that $38 \%$ of the respondents use the calculator to support coursework. The relative high percentage associated with this category arose from the fact that the calculator is one of the commonest features found in every mobile phone - be it feature phone or smart phone. The category "whatsAPP" has neither the highest frequency nor the lowest frequency despite its growing popularity. The relative low number of respondents in this class isa reflection of the fact that students are not all that conversant with it. Video camera category is trailing with $0.5 \%$ of the respondents. This is because text data is generally more dominant than video data in students' coursework and video data consumes a lot of memory space. It is also as a result of the fact that many lecturers do not subscribe to videoing their lectures.

Table 1: Activities students use mobile phone to support

\begin{tabular}{|l|l|l|}
\hline & Frequency & Percent \\
\hline Store Or Retrieve E-books & 94 & 54.3 \\
\hline $\begin{array}{l}\text { Booking Appointment with } \\
\text { Lecturer }\end{array}$ & 20 & 11.6 \\
\hline Take Lecture Notes & 27 & 15.6 \\
\hline Online Evaluation test & 8 & 4.6 \\
\hline Submission of Assignment & 24 & 13.9 \\
\hline Total & 173 & 100.0 \\
\hline
\end{tabular}


From table 1, coursework activities like storing and retrieving e-books using the mobile phone are carried out by majority of the respondents (54.3\%). This outcome gives strong credence to the findings of Guy (2009) that internet-enabled mobile phone can sustain a lot of learning activities. In the same vein, $11.6 \%$ and $15.6 \%$ of the respondents say they use their mobile phones to book appointment with lecturers and use them to take lecture notes respectively. The respondents with the lowest frequency are those who use their mobile phones for online evaluation test. This is an indication of the fact that lecturers do not subscribe to on-line assessment platform.

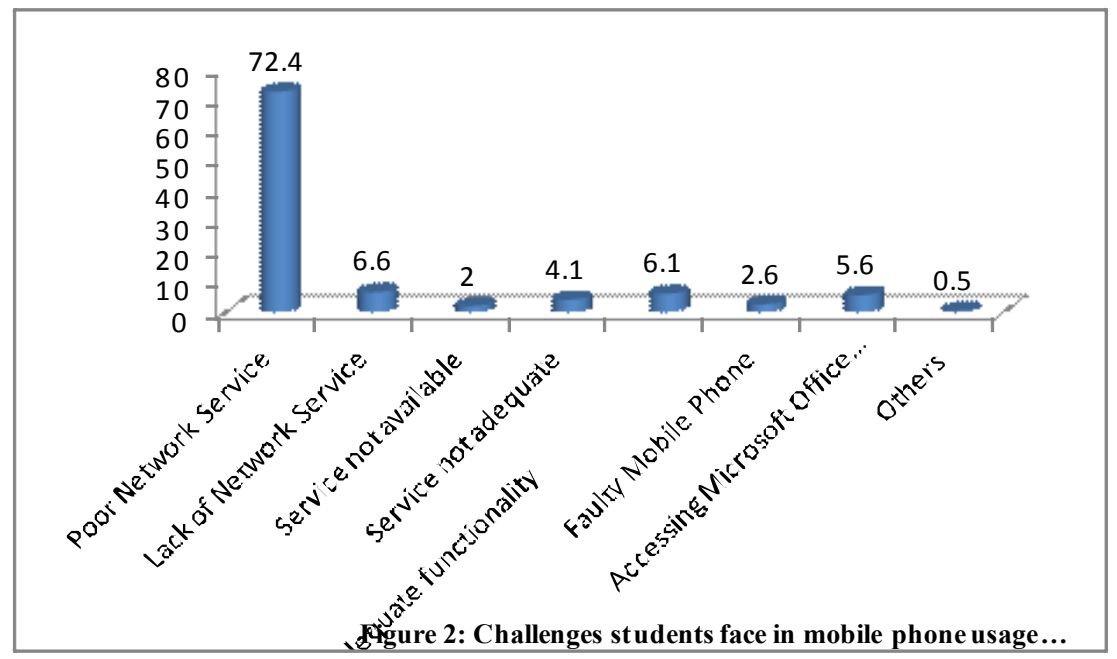

Despite the enormous benefits that arise as students use mobile phone to engage in coursework, its usage usually poses some challenges. Osang, Ngole and Tsuma (2013) affirms this issue as they explain that some mobile phone applications cannot support academic work. Figure 2 reaffirms that assertion as $5.6 \%$ of the respondents do not have Microsoft Office to enable them effectively access coursework. Furthermore, the most striking challenge which students face is poor network service whose percentage stands at 72.4 . 
Table 2: Poor Network Service

\begin{tabular}{|l|l|l|}
\hline & Frequency & Percent \\
\hline Mild & 29 & 20.1 \\
\hline Moderate & 80 & 55.6 \\
\hline Severe & 33 & 22.9 \\
\hline Profound & 2 & 1.4 \\
\hline Total & 144 & 100.0 \\
\hline
\end{tabular}

About fifty-six percent of the respondents saidthey experience moderate network service. This figure justifies why majority of respondents in Figure 1 engage in text message service quite often. A little above one percent experience profound poor network service.

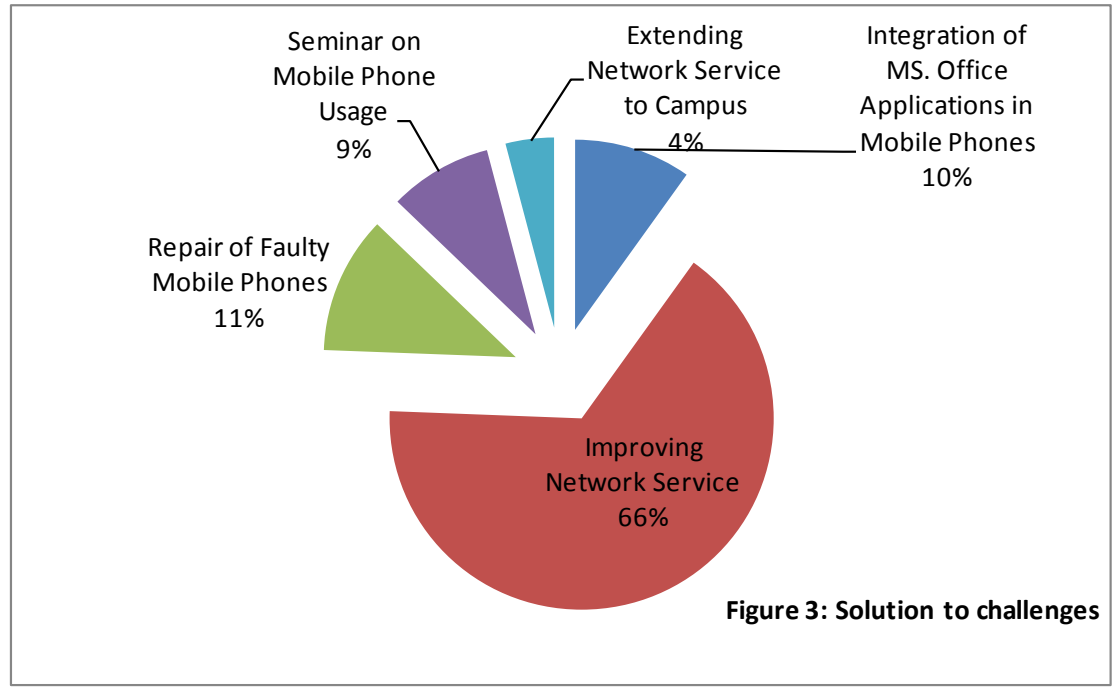

As regards solutions to the challenges, $72.4 \%$ of the respondents said poor network service was their biggest challenge. Sixty-six percent of the respondents said that an improvement in network service is the most important solution to their challenges. This is in the right direction. However, organising training programmes, the use of Microsoft Office applications on phones and the frequent and timely repair of mobile phones are equally important as their cumulative percent stands at 47.0. Therefore, all the challenges identified need equal attention. For instance, if the network service is improved and students are not adequately trained on how to use the mobile applications to engage in coursework, efforts made toimprove the network service may not yield the necessary benefits. 


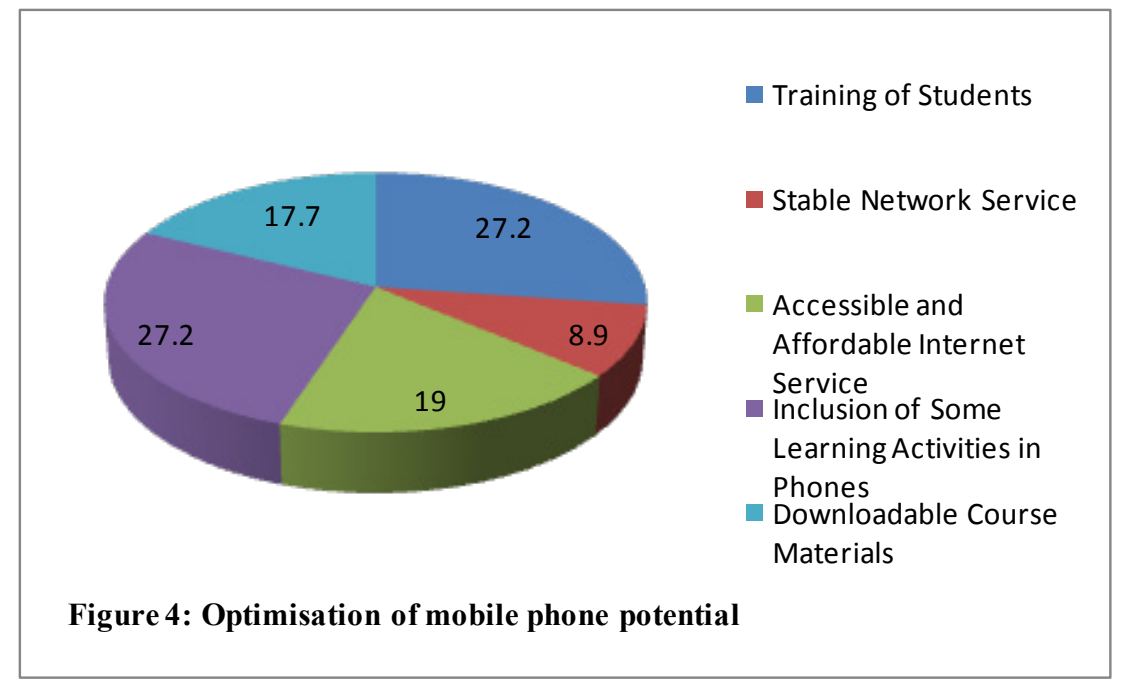

From figure 4, two categories of the respondents, $27.2 \%$ each, totaling more than $50 \%$ are of the opinion that training students how to use mobile phone to support coursework and the incorporation of mobile phone in some learning activities are some of the best ways to harness the potential of the mobile device. The smallest frequency $8.9 \%$ is associated with students who express the view that the network service should be more stable. The low incidence of respondents' response concerning "Stable Network Service" underscores the fact that network stability alone is insufficient to exploit the full potential of the mobile phone. Customised mobile phones applications, such as Microsoft Office enable students to use them to support learning.

\section{Conclusion}

The study investigated how students in Wa Polytechnic use the mobile phone to support coursework. A survey design was used to obtain data from respondents. The study revealed that students of Wa Polytechnic effectively use mobile phones for academic purposes such as storage and retrieval of e-books, taking of lecture notes, taking online evaluation and submission of assignments. It was found out that the calculator is the most frequently used feature because it is one of the commonest features of mobile phones. The major challenge that students face as they use mobile phones to support coursework is poor network service. It is recommended that mobile phone service providers make available their network services at all times to the students to facilitate their accessibility to the internet and the web for course materials. Stakeholders such as mobile phone vendors should trade in mobile phones customised with Microsoft Office application to enable students to use them to support learning. The study was confined to Wa Polytechnic and its findings are not applicable to other polytechnics. Therefore there is 
the need for further research in this area to cover all Polytechnics in the country so as to have diverse perspectives that will lead to a generalized conclusion.

\section{References}

Academic Administration. (2010). Law 2010 faculties of the University of Pretoria. Pretoria, South Africa. http://www.up.ac.za/faculty-of-law. Accessed: 3oth June 2014.

Allotey, F.K. and Arkorli, F. K. (1999).Telecommunication in Africa, Oxford: Oxford University Press.

Bradley, C., Smith, C. and Cook, J. (2010 in press) Location and context sensitive mobile learning: The evaluation of an urban education tour, Proceedings of MoLeNET mobile learning conference 2009, 1 December, London.

Bradley, C., Weiss, M., Davies, C. and Holley, D. (2010). A little less conversation, a little more texting please - A blended learning model of using mobiles in the classroom, 5th International Blended Learning Conference, 16-17 June 2010.

Commonwealth of Learning (2008). Using of mobile technology for learner support in open schooling. Available at: www.paddle.usp.ac.fj/collect/paddle/index/assoc/ coloo8.dir/doc.pdf.Accessed: 3oth October 2012.

Cui, G., and Wang, S. (2008). Adoption cell phones in EFL teaching and learning. Available at: www.notworthprinting.wordpress.com/category/mobile-learning.Accessed: $31^{\text {st }}$ October 2013.

Dansieh, A. S. (2011). SMS texting and its possible links to students' written communication. Journal of Polytechnics in Ghana, 5 (1), pp. 1-16.

Deubel, P. (2009). Mobile devices: Facing challenges and opportunities for learning. Available at: http://hejournal.com/articles/2009/03/19/mobile-devices-facingchallenges-and-opportunities-for-learning.aspx. Accessed: 2oth January 2014.

Ferry, B. (2008). Using mobile phones to augment teacher learning in environmental education. In Hello! Where are you in the landscape of educational technology? Proceedings ascilite Melbourne 2008. http://www.ascilite.org.au/conferences/ melbourneo8/procs/ferry.pdf. Accessed: 10th June 2014.

Frempong, G., George, E. and Emmanuel, T. (2007). Survey on the use of mobile telephones for micro and small business development: The case of Ghana, STEPRI, and Accra (CSIR).

Ghanaweb. (2013). Cellular/mobile network. Available: http://www.ghanaweb.com/ GhanaHome

Page/communication/mobile.php. Accessed 16th August 2013. 
GhanaWeb. (2013). Telephones and communication. Available at: http://www.ghanaweb. com/Ghana HomePage/communication/mobile.php. Accessed 20 ${ }^{\text {th }}$ August 2013.

Guy, R. (2009). Theevolution of mobile teaching and learning. California, Informing Science

HOPKE, K. D. (2009). Studentcell phone use in college classrooms. National Undergraduate Research Clearinghouse, 12. Available at: http://www.webclearinghouse.net/ volume/. Accessed 15 October, 2014.

Huang, Y-M., Hwang W-Y. and K.,-E. (2010). Innovations in designing mobile learning applications.Available: $\quad$ www.ifets.infor/download pdf.php?j id=48\&a id=1056. Date Accessed: $28^{\text {th }}$ October 2013.

Kafyulilo, A. (2012). Access, use and perceptions of teachers and students towards mobile phones as a tool for teaching and learning in Tanzania. Educational and Information Technologies Journals. Available at: Htt://rd. springer.com/article/10.1007/s10639012-9207-y. Accessed October 31, 2012.

Kajumbula, R. (2006). The effectiveness of mobile short messaging service (SMS) technologies in the support of selected distance education students of Mekerere University, Uganda. Paper presented at the forth Pan-Commonwealth Forum (PCF4) on Open Learning, Ochio Rios, Jamaca. Available at: http://pcf4.dec.uwi. edu/viewpaper.php?id=98. Date Accessed: $17^{\text {th }}$ February 2014 .

Kirschner, P. and Selinger, M. (2003). The state of affairs of teacher education with respect to information and communications technology. Technology, Pedagogyand Education, 12(1), pp. 5-17.

Kukulska-Hulme, A., Evans, D. and Traxler, J. (2005) Landscape study on the use of mobile and wireless technologies for teaching and learning in the post-16 sector. http://www.jisc.ac.uk/whatwedo/programmes/elearninginnovation/outcomes

Liaw, S., Hatala, M. and Huang, H. (2010). Investigating acceptance toward mobile learning to assist individual knowledge management: Based on activity theory approach. Computers in Education, 54 (2), pp. 446-454.

Michelsen, G. G. (2003). Institutional legacies at work in Africa Telecommunication. Report 8o, Bergen: Department of Administration and organisation theory, university of Bergen.

National Communication Authority. (2009). Annual report 2008, NCA - Ghana.

Osang, F.B., Ngole, J. and Tsuma, C. (2013). Prospects and Challenges of Mobile Learning Implementation in Nigeria: Case Study National Open University of Nigeria (NOUN), International Conference on ICT for Africa 2013, February 20-23, Harare Zimbabwe.

Overa, R. (2006). Network, distance and trust. Telecommunication development and changing trade practices in Ghana. Chr. Michelsen Institute, Norway. 
Schuck, S., Aubusson, P., Kearney M. and Burden, K. (2010). Mobagogy: mobilelearning for higher education community. In proceedings of the IADIS mobile learning, 2010 conference in Porto, Portugal, pp. 69-76.

Students' Handbook. (2014). Students' Handbook for the 2014-2015 Academic Year. Villanova University School of Law. Available at: http://www1.villanova.edu/ content/dam/villanova/law/documents/forms/currstuhandbooks/Student\%20 Handbook.pdf

Tinio, V. L. (2003). ICT in education for development. United Nations Development Programme Bureau for Development policy 304 E. 45 ${ }^{\text {th }}$ Street New York, NY 10017.

UNESCO (2012). Mobile learning for teachers in Africa and the Middle East: Exploring the potentials of mobile technologies to support teachers and improve practices. Available at: unesdoc.unesco.org/images/o021/o02163/216358e.pdf. Accessed: $31^{\text {st }}$ October 2012.

University for Development Studies. (2014). General and examination rules and regulations on first degree and diploma programmes. Tamale: Muet Press.

University of Education. (2014). Undergraduate students' handbook on rules and regulations. Academic Affairs, Winneba.

Utulu, C.S. (2012). Use of mobile phones for project based learning by undergraduate students of Nigerian private Universities. International Journal of Education and Development usingInformation Communication and Technology, 8 (1), pp. 1 - 15.

Valk J. H., Ahmed, T. R. and Laurent, E. (2010). Using mobile phones to improve educational outcomes: An analysis of evidence from Asia. Pan Asia Networking, IDRC: Canada. Available at: http://www.irrodl.org/index.php/irrodl/article/view/794. Accessed: $21^{\text {st }}$ October 2013.

Wa Polytechnic. (2009). Students' Handbook (Revised ed), Wa Polytechnic.

Wijekumar, K. (2005). Creating effective web based learning environments. Relevant Research and Practice Innovate. Available at: http://www.innovateonline.info/index. php?view=article\&id=26. Accessed: $20^{\text {th }}$ February 2014.

Wulystan P. M., Ronald B., Andrew C. M. and Rachel S. (2012). Using mobile phone for teaching and learning purposes in higher learning institutions: the Case of Sokoine University of Agriculture in Tanzania. Proceedings and report of the 5 th UbuntuNet Alliance annual conference, pp. 118-129. 